\author{
Л.І. ЗАКРУТЬКО \\ А.О. ЗАКРУТЬКО, Д.О. КОЛГАН
}

\title{
ВИВЧЕННЯ ПОПИТУ ЩОДО БЕЗПЕРЕРВНОЇ МЕДИЧНОЇ ОСВІТИ ТА ПРОФЕСІЙНОГО РОЗВИТКУ ПРАЦІВНИКІВ СФЕРИ ОХОРОНИ ЗДОРОВ'Я ДЛЯ ПІДВИЩЕННЯ ЇХ ПРОФЕСІЙНОЇ КОМПЕТЕНЦІї У НАДАННІ ДОПОМОГИ ПАЦІЄНТАМ
}

\author{
1Український центр наукової медичної інфрормації та патентно-ліцензійної роботи МОЗ України, \\ м. Київ, Україна \\ 2ГО «Всеукраїнська спілка безперервної медичної освіти», м. Київ, Україна \\ ${ }^{3}$ ВДНЗ України «Буковинський державний медичний університет», м. Чернівці, Україна \\ ${ }^{4}$ Національний медичний університет ім. О.О. Богомольця, м. Київ, Україна
}

\footnotetext{
Метою дослідження було вивчення попиту щодо забезпечення медичних фрахівців знаннями, інструментами та ресурсами для підвищення їхньої профресійної ефективності в наданні медичної допомоги.

Матеріали і методи. Проведено опитування науковців у сфері охорони здоров'я України. Використано методи анонімного опитування, статистичний, аналітичний.

Результати. У статті розглядаються питання вивчення попиту щодо забезпечення медичних фрахівців знаннями, інструментами та ресурсами для підвищення їхньої професійної ефективності у наданні медичної допомоги.

Висновки. Отримані дані дозволили дослідити та вийти на обґрунтування існуючої потреби та прогалин щодо інформування, забезпечення та надання якісного інструменту щодо підвищення якості забезпечення та фрахової майстерності спеціалістів і, як наслідок, надання якісної медичної допомоги пацієнтам.
}

КЛЮчОВІ СЛОВА: єдиний інформаційний простір, безперервна медична освіта, професійний розвиток, надання допомоги.

Глобалізація інфрормаційних потоків у всіх сорерах діяльності, у тому числі в медицині, призвела до якісно нових проблем при прийнятті рішень. Потік медичної інфрормації щороку зростає, кількість медичних видань не зменшується [1-6]. Забезпечення та створення гнучкої, цілеспрямованої, ефективної системи сприятиме формуванню єдиного інфрормаційного простору [1;3].

Метою дослідження було вивчення попиту щодо забезпечення медичних фрахівців знаннями, інструментами та ресурсами для підвищення їх професійної ефективності в наданні медичної допомоги.

Матеріали і методи. Проведено опитування науковців у сорері охорони здоров'я України. Використано методи анонімного опитування, статистичний, аналітичний.

Результати дослідження та їх обговорення. У межах цього дослідження було проведено анонімне опитування науковців у сорері охорони здоров'я України (середня тривалість наукового

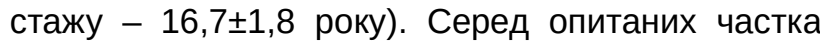
докторів наук становила 11,5\%, кандидатів наук 80,8\%, без наукового ступеня - 7,7\%; 69,3\% фрахівців третинної і 30,7\% вторинної ланок допомоги.
Медична спеціальність респондентів відповідала хірургічному напряму.

При експертному опитуванні досліджувалися наукові комунікації щодо розповсюдження результатів досліджень у професійному комунікаційному середовищі (доповіді на наукових форумах, навчання фрахівців новим технологіям профілактики, діагностики, лікування, реабілітації, диспансеризації, публікування в мережі Інтернет, демонстрація на спеціалізованих виставкових заходах тощо).

За результатами опитування «щодо інформації, якій науковці довіряють» було отримано наступні відповіді: накази МО3 України, Уніфіковані клінічні протоколи - 42,3\%, наукові публікації у фрахових виданнях - 42,3\%, матеріали зі статистично доведеною достовірністю (метаналіз, Кокранівські огляди, результати подвійного сліпого рандомізованого дослідження) - 19,2\%, доповіді на наукових форумах - 23,1\%, методичні (міжнародні, практичні) рекомендації - 23,1\%, клінічні настанови - 7,6\%, фрахові публікації в іншомовних виданнях - 3,8\%.

Важливим питанням $€$ безперервна медична освіта та професійний розвиток працівників 
ссрери охорони здоров'я. Серед опитаних 61,5\% респондентів надавали перевагу навчанню на передатестаційних циклах, курсах, 53,8\% - відвідуванню конференцій, 23,1\% - самоосвіті.

Впровадження результатів досліджень залежить від обізнаності та ставлення самого науковця до заключного етапу наукової діяльності. У $26,9 \%$ респондентів уявлення щодо впровадження результатів досліджень пов'язане з отриманням актів впровадження, $23,1 \%$ оприлюднюють результати власних досліджень при лікуванні хворих та через наукові публікації, 7,6\% - виступи на наукових форумах, $3,8 \%$ - на засіданнях асоціації, 15,3\% - в інсрормаційних листах.

При дослідженні питання доступності отримання інфрормації про наукову та інноваційну продукцію, призначену для використання у сорері охорони здоров'я України, 3 використанням сучасних інформаційних технологій виявлено, що $100 \%$ респондентів отримують інформацію без перешкод через мережу Інтернет.

У відповідь на питання «щодо пропозицій 3 есрективного забезпечення інформації про наукову та інноваційну продукцію» 61,5\% респондентів запропонували адресну розсилку через мережу
Інтернет, 23,1\% - через засоби масової інорормації та $15,4 \%$ - поштову розсилку, яку виконує Український центр наукової медичної інформації та патентно-ліцензійної роботи МОЗ України.

Серед пропозицій щодо «ефективного впровадження результатів власних досліджень» $73,1 \%$ респондентів назвали покращення матеріальної бази, 3,8\% - зібрання 3 метою роз'яснювальної, методичної роботи та оголошень, 26,9\% не мали пропозицій.

\section{Висновки}

Результати опитування дозволили дослідити та вийти на обґрунтування існуючої потреби та прогалин щодо інфрормування, забезпечення та надання якісного інструменту щодо підвищення якості забезпечення та підвищення фрахової майстерності спеціалістів, і, як наслідок, надання якісної медичної допомоги пацієнтам.

Перспективи подальших досліджень полягають у пошуку шляхів забезпечення та надання якісного інструменту щодо зростання якості забезпечення та підвищення фрахової майстерності спеціалістів і, як наслідок, надання якісної медичної допомоги пацієнтам.

\section{Список літератури}

1. Єсімов С. С. Формування єдиного інформаційного простору в діяльності державних органів України [Електронний peсурс]. - Режим доступу : http://science.lp.edu.ua/sites/default/files/Papers/yesimov_0.pdf

2. Киричок И. В. Проблемно-ориентированные базы данных в помощь университетской науке / И. В. Киричок, С. А. Кравченко [Электронный ресурс]. - Режим доступа: http www.google.com.ua/search.

3. Медична освіта у світі та на Україні (Дипломна освіта, післядипломна освіта, безперервний профресійний розвиток) / Ю.В. Поляченко, В.Г. Передерій, О.П. Волосовець [та ін.].- Київ : Книга плюс, 2005. - 384 с.

Подліанова О.І. Безперервний професійний розвиток лікарів-педіатрів-досвід роботи кафедри / О.І. Подліанова // Медична освіта. Вісник проблем біології і медицини. - 2014. - Вип. 4, Т. 2 (114). - С. 55-57.

4. Проценко T. Галузеві бібліотечні ресурси в інформаційному забезпеченні сімейних лікарів:сучасний стан та проблеми використання в работі / Т. Проценко [Електронний документ]. - Режим доступу: http://irbis-nbuv.gov.ua. Назва з екрану.

5. Юрьев К.Л. Доказательная медицина. Кокрановское сотрудничество / К. Л. Юрьев, К. Н. Логановский // Український мед. часоп. - 2000. - № 6 (20) - XIXII. - С. 6-15.

\section{References}

1. Yesimov, S.S. Formuvannya yedy`nogo informacijnogo prostoru v diyal’nosti derzhavny`x organiv Ukrayiny` [Forming of one information space in the government agencies activity of Ukraine] (n.d.). science.lp.edu.ua. Retrieved from http:// science.Ip.edu.ua/sites/default/files/Papers/yesimov_0.pdf [in Ukrainian].

2. Kirichok, I.V., Kravchenko, S.A. Problemno-orientirovannye bazy dannyh v pomoshh' universitetskoj nauke / [Problemoriented data base for university science] (n.d.). google.com.ua. Retrieved from http://www.google.com.ua/search [in Russian].

3. Polyachenko, Yu.V., Perederij, V.G., Volosovecz`, O.P. et al. (2005) Medy`chna osvita u sviti ta na Ukrayini (Dy` plomna osvita, pislyady plomna osvita, bezperervny j profesijny j rozvy` tok) [Medical education in the world and in Ukraine (Diploma education, postgraduate education, uninterrupted professional development)]. Kyiv: Kny`ga plyus [in Ukrainian].

4. Podlianova, O.I. (2014) Bezperervny`j profesijny`j rozvy`tok likariv-pediatriv-dosvid roboty` kafedry` [Uninterrupted professional development of pediatricians - expertise of the department]. Medy chna osvita. Visny`k problem biologiyi $i$ medy cy'ny' - Medical Education. Journal of Medical and Biological Problems, issue 4, Vol. 2 (114), 55-57 [in Ukrainian]. Procenko, T. (2007). Galuzevi bibliotechni resursy` v informacijnomu zabezpechenni simejny`x likariv:suchasny j stan ta problemy` vy kory`stannya v raboti [Branch library resources in information support of family physicians: current situation and problems of using in work]. irbis-nbuv.gov.ua. Retrieved from http://irbis-nbuv.gov.ua [in Ukrainian].

5. Yurev, K.L., Loganovskiy, K.N. (2000) Dokazatelnaya meditsina. Kokranovskoe sotrudnichestvo [Evidencing medicine. Kokranov's cooperation]. Ukrayins`ky`j medy`chny j chasopy`s - Ukrainian Medical Journal, 6 (20), XIXII, 6-15. 
ИЗУЧЕНИЕ СПРОСА НА НЕПРЕРЫВНОЕ МЕДИЦИНСКОЕ ОБРАЗОВАНИЕ И ПРОФЕССИОНАЛЬНОЕ РАЗВИТИЕ РАБОТНИКОВ СФЕРЫ ЗДРАВООХРАНЕНИЯ ДЛЯ ПОВЫШЕНИЯ ИХ ПРОФЕССИОНАЛЬНОЙ КОМПЕТЕНЦИИ В ОКАЗАНИИ ПОМОЩИ ПАЦИЕНТАМ

Л.И. Закрутько, А.Е. Горбаньㄹ, Л.А. Филиппенкова ${ }^{2}$, О.В. Мислицькийㄱ, А.А. Закрутько, Д.О. Колган

1Украинский центр научной медицинской информации и патентно-лицензионной работы МЗ Украины, г. Киев,

Украина

${ }^{2} \mathrm{OO}$ «Всеукраинский союз непрерывного медицинского образования», г. Киев, Украина

${ }^{3}$ ВГНЗ Украины «Буковинский государственный медицинский университет», г. Черновцы, Украина

${ }^{4}$ Национальный медицинский университет им. А.А. Богомольца, г. Киев, Украина

Целью исследования было изучение спроса по обеспечению медицинских специалистов знаниями и ресурсами для повышения их профессиональной компетенции в оказании медицинской помощи.

Материалы и методы. Проведен опрос ученых в сфрере здравоохранения Украины. Использованы методы анонимного опроса, статистический, аналитический.

Результаты. В статье представлены результаты опроса по обеспечению медицинских специалистов знаниями и ресурсами для повышения их профессиональной компетенции в оказании медицинской помощи.

Выводы. Данные опроса позволили выйти на существующую потребность и пробел в инсормировании, обеспечении и предоставлении знаний с целью обеспечения профессионального мастерства специалистов и, как следствие, предоставления качественной медицинской помощи пациентам.

КЛЮЧЕВЫЕ СЛОВА: единое информационное пространство, непрерывное медицинское образование, оказания помощи.

\section{DEMAND EXPLORING OF UNINTERRUPTED MEDICAL EDUCATION AND PROFESSIONAL DEVELOPMENT OF HEALTHCARE SECTOR PROFESSIONALS FOR IMPROVING THEIR PROFESSIONAL COMPETENCE IN PROVIDING HELP TO PATIENTS \\ L. Zakrutko1, A. Gorban ${ }^{1}$, L. Filippenkova², O. Myslytskyy'1, A. Zakrutko ${ }^{3}$, D. Kolhan ${ }^{4}$ \\ ${ }^{1}$ Ukrainian Center for Scientific Medical Information and Patent License of Ministry of Health of Ukraine, Kyiv \\ ${ }^{2} \mathrm{NGO}$ «All-Ukrainian Union of continuing medical education", Kyiv \\ ${ }^{3}$ Bukovinian State Medical University, Chernivtsi \\ ${ }^{4}$ National Medical University O. O. Bogomolets, Kyiv}

The aim of the research was to explore the demand in providing medical professionals by knowledge, tools and resources for increasing their professional effectiveness in health care.

Materials and methods. A survey of scientists in healthcare sector of Ukraine was provided. The anonymous survey, statistical and analytical methods were used.

Results. The points about demand exploring in providing medical professionals by knowledge, tools and resources for increasing their professional effectiveness in health care are considered in the article.

Conclusions. Identified survey data have given the opportunity to explore and prove existing needs and gaps which are connected with informing, supporting and providing qualitative tools for improving quality and increasing of professional skills of specialists and, as a result, providing qualitative patient care.

KEY WORDS: one information space, uninterrupted medical education, professional development, providing of medical help.

Рукопис надійшов до редакції 05.04.2017 p.

Відомості про авторів:

Закрутько Л.І. - к.мед.н., доц., заступник директора з наукової роботи Українського центру наукової медичної інсрормації та патентно-ліцензійної роботи МОЗ України; тел. служб.: +38(044) 428-37-22.

Горбань А.Є. - к.мед.н., директор Українського центру наукової медичної інорормації та патентно-ліцензійної роботи МОЗ України; тел. служб.: +38(044) 428-37-22.

Салютін Р.В. - д.мед.н., заступник директора з лікувальної роботи Національного інституту хірургії та трансплантології ім. О.О. Шалімова; тел. служб.:+38(044) 408-18-00.

Філіппенкова л.о. - президент ГО «Всеукраїнська спілка безперервної медичної освіти».

Мислицький О.В. - н.с. Українського центру наукової медичної інорормації та патентно-ліцензійної роботи МОЗ України, голова ГО «Українська асоціація медичної інфрормації»; тел. служб.: +38(044) 428-37-22.

Закрутько А.О. - студентка ВДНЗ України «Буковинський державний медичний університет», член ГО «Українська асоціація медичної інформації».

Колган Д.О. - студентка Національного медичного університету ім. О. О. Богомольця, член ГО «Українська асоціація медичної інформації». 